\title{
Lawyers, Jails, and the Law's Fake Bargains
}

MR monthlyreview.org/2001/07/01/lawyers-jails-and-the-laws-fake-bargains/

by Michael E. Tigar Topics: Incarceration , Inequality , Political Economy

Michael Tigar is a leader of the U.S. Bar, and at the same time an avowed radical and activist for social justice. He is Professor of Law at Washington College of Law, American University, Washington, D.C., and the author of Law \& the Rise of Capitalism, now in a new edition (Monthly Review Press, 2000).

Assume that Canada and the Western European countries have about the right number of people in jail. Assume that the social problem of crime is not terribly different in those countries than in the United States. Understand that our incarceration rate is five to eight times that of those other countries. If these assumptions, and this understanding, are even nearly valid, 80 percent of the people in American jails should not be there.

The heavy toll of jailed people reflects the extent to which the criminal process is used as a mechanism of social control, directed mainly at the poor and at people of color. That is what I term the substantive aspect of the issue, which could also be called over-criminalization. Minor social deviance makes you subject to criminal punishment, and for terms that dwarf those imposed in other countries.

The proceduralist would tell us that these figures are not reason for alarm, for every person faced with incarceration has an array of due process rights. I sat at dinner with a Supreme Court Justice, who explained to me that the constitution was drafted by people who had read Isaac Newton, and who devised a mechanism of checks and balances, like clockwork. The Framers, he said, were concerned with the mechanism of government. This view is, to be sure, partial; the Framers had been revolutionaries, battlers for a certain social vision, threatened with jail or execution themselves. They were also white males who owned property, and many, if not most, of them counted human beings among their property. However, the clockwork idea is powerful, for it reveals something of current Supreme Court attitudes towards the criminal process that puts all these people behind bars.

Clockwork is a powerful image because a clock is quintessentially "form," the substance is what time it is. If there is only one clock, and it is kept by a small group of the powerful, then the time is whatever they say it is. The clock, and even the rather arbitrary decision to divide its units into sixty, sixty and twelve or twenty-four, is itself a convention established by somebody or other. "Twelve o'clock and all's well," says the town crier from the castle parapet. In this essay, I want to talk about how, procedurally, all those people could have been put into jail or onto death row.

Before I talk about the substance of bargains between lawyers and clients and between lawyers and the state, I must speak about bargain as a form. The property norm speaks of a relationship between an individual and a thing. Unlike feudal social relations, which were expressly based on dominion of people over other people, capitalist social relations are premised on domination only of inanimate objects and of whatever animals may lawfully be killed, sold and eaten. This form, however, masks the substance of capitalism, which is that some people own means of production and others own only their labor power. Ownership of means of production translates into domination over people as owners of labor power sell that commodity.

"Not so fast!" says the listener. The worker sells labor power in a free bargain. This is the form called "contract." A contract involves the exchange of mutual promises by individuals who are each free to accept or reject the terms proposed. In the contract for labor, however, we can see the way in which this formalism is belied by substance. The worker has nothing to sell but labor power. The price is dictated by market forces beyond the worker's control. The individual is powerless relative to the employing enterprise. The intervention of collective bargaining may help equalize the balance, but only so far. And this is not to speak of the take-it-or-leave it pseudo-bargains that are everywhere in an economy dominated by powerful sellers and buyers. 
Legal counsel is at the center of the formalistic bargain that dominates the criminal process. The constitution is explicit: "No person shall be held to answer except..." "the accused shall enjoy...", and similar phrases introduce enumerated rights of a person charged with or suspected of crime. Among these rights is "assistance of counsel." We must therefore define the multiple bargains by which this promise of counsel is fulfilled.

The first such bargain is the one spelled out in the Bill of Rights. Like all the other enumerated rights, this is a promise by an ostensibly neutral state, as a condition of the overall deal struck by "We the People" who established the Constitution to begin with. The state, dominated by owners of property including slaves, guarantees certain rights, the scope of which it will interpret. Whether this bargain means anything depends, here as in all its other aspects, on who is wielding the levers of state power.

That brings us to the lawyers. Regardless of how biased may be the judge, how inhumane the criminal law, and how corrupt and malignant the police and prosecutors, the accused will have a champion, a lawyer. I state the issue in this fashion because its premise has been documented over and over. A Columbia Law School study found fundamental legal error in two-thirds of the capital cases tried in the United States since capital punishment was upheld by the Supreme Court in 1978 subject only to certain broad limits. Most of those errors involved police officials hiding exculpatory evidence, prosecutors and police denying the accused basic rights in the criminal justice system, and judges who overlooked those errors. Many of these judges, particularly in the Death Belt states of the American South, are elected in campaigns designed to fire up the vengeful spirit of the majority community. This Columbia study reaffirmed what has been clear for so many years and what is borne out by looking at the racial composition of death rows. Crimes committed against whites by African Americans are far more likely to be prosecuted as capital than those committed in any other combination of victim and killer. It is easy to see why a system so dominated by racial disparity would tolerate the other errors that the Columbia study found.

The capital cases are not unique in being corrupted by error; it is only that they have been studied most closely. It is of course rare for a defendant to agree to a capital sentence, and so those cases are usually tried. Ninety percent of criminal cases end with a guilty plea to the charged offense or some lesser one. These are "plea bargains." Typically, the defendant agrees to waive all claims of legal error, whether it be denial of counsel at arrest, illegal search, failure to disclose exculpatory evidence, or whatever. In addition, in most cases the defendant also waives the right ever to bring a later challenge to the legality of the proceedings by appeal or otherwise. Of course, the defendant making such a bargain has counsel provided by the state, and stands before the judge to make public avowal that he or she is acting voluntarily and with full information.

The bargain between the defendant and defense counsel is, like all bargains, limited and defined by the state. I say "like all bargains" because "freedom of contract" is a myth. Its mythic character appears in part because some bargainers own the means of production and some do not. It is also a myth because countless so-called bargains are enforced by the state even though there is no semblance of freedom about them.

In the nineteenth century, there were a number of cases in which workers who did not speak English were hired for an agricultural season of labor, and if they quit before the season was over, they received no money at all. The courts routinely held that this was the nature of their "free bargain" even though the workers had no real understanding of its terms. Today, there are countless instances of "contracts of adhesion," in which the consumer or worker with limited bargaining power and sophistication is bound to a deal that he or she did not understand and in which there was no real choice.

In the context of lawyer-client relations, defense counsel must function as an "officer of the court" as well as champion of the accused. Thus, counsel may be obligated to withdraw from the case, or to report on the client, if counsel concludes that the client is not telling the truth.

Counsel's right to defend the client in the forum of public opinion has also been limited by the Supreme Court. The lawyer may be punished for making a public statement substantially likely to have an adverse effect on the pending proceedings. This limitation can be very important when the client is the victim of government wrongdoing such as 
planting false evidence or selecting defendants based on political or racial considerations. Who better than the lawyer to make a public statement about that sort of government misconduct? The framers of the Bill of Rights thought it was important for lawyers to be effective participants in public debate, but the contemporary Supreme Court sees matters differently.

Then, too, it is a myth to say that even the richest defendant can afford to hire investigators and experts on a par with those to whom the state has access. There are few exceptions to this principle. And of course, the vast majority of criminal defendants are poor and, all out of proportion to their numbers in the population, people of color. As to this selectivity, the Supreme Court has turned a nearly-blind eye. The Court has refused to place many limits on the exercise of prosecutorial and police discretion.

Many people of good will were shocked by the conduct of Independent Counsel Kenneth Starr's investigation of the Clinton White House. Witnesses were bullied and threatened. When a witness (like Monica Lewinsky) wanted a lawyer present during questioning, she was cajoled and insulted for expressing such a preference. Inflammatory press leaks seemed to be the normal course of business. However, as one law professor put the matter in the title of a leading journal article, "Starr is to Clinton as Regular Prosecutors are to Blacks."

In sum, even in its idealized form, the contract between the attorney and the wealthy client is hampered by stateimposed limits on the nature of the bargain, and by the superior power of the state apparatus that the lawyer and client must confront.

This brings us to the bargain between the accused and court-appointed counsel. This is a bargain only in the most formal sense. The indigent accused will have the services of a lawyer selected by the judge, and paid only what the local custom will allow. That payment may be so low that the lawyer's most financially-rewarding course is to take on as many appointed cases as possible and make as many plea bargains as quickly as possible. Although figures are difficult to obtain, about 90 percent of all criminal defendants, and an even higher percentage of defendants of color, have court-appointed counsel.

The National Law Journal did a study of appointed counsel in capital cases in 1990. Given what is at stake, one would expect that only the most qualified lawyers would be found adequate to the task. By now, almost everyone has read the anecdotal evidence that this is not so. The classic story of the Texas appointed lawyer who slept during his client's capital murder trial has made the rounds. The trial and penalty phase lasted just thirteen hours, and the lawyer did not even make objection when the prosecutor said the jurors should sentence the defendant to death because he is gay.

Here is a short summary of what the National Law Journal found:

- the trial lawyers who represented death row inmates in the six states were disbarred, suspended, or otherwise disciplined at a rate three to forty-six times the discipline rates for lawyers in those states

- there were wholly unrealistic statutory fee limits on defense representation

- nonexistent standards for appointment of counsel

- capital trials that were completed in one to two days, in contrast to two-week or two-month long trials in some states...where indigent defense systems were operating.

In short, the right to effective counsel is ignored in the cases where the stakes are highest, and error rates are demonstrably high. The idea that a capital case can be well-tried in one or two days is laughable. In the Oklahoma City bombing trial of Terry Nichols, jury selection alone took five weeks in order to get a panel that was willing to swear it could overcome the media barrage. The trial itself took nearly three months. The defense called more than one hundred witnesses. The jury acquitted Nichols of murder, finding him guilty of lesser charges, and voted not to impose a death penalty. This result was achieved only because counsel had the dedication and resources to combat the government. 
In non-capital cases, the situation is every bit as bleak. In April 2001, the New York Times published the results of a long investigation into the provision and performance of appointed counsel in New York City. It found that appointed counsel are paid at rates that actively discourage them from spending enough time on cases. The only way to make the appointed practice pay is by taking on hundreds of cases per year and spending as little time as possible on each one. The Times' "poster lawyer" was one Sean Sullivan. Sullivan handles sixteen hundred cases per year, and earned more than $\$ 125,000$ in 2000 for his efforts. The "representation" he provides is worse than minimal. He does not confer with clients, does not return client phone calls, does not prepare needed legal motions, and contents himself with working out quick plea bargains on an assembly-line basis.

The hapless client who goes to prison as the result of such bungling may then be handed off to an appellate lawyer whose inattention to the case is about the same. As a result, claims of ineffective assistance are rarely made.

Many appointed lawyers buck this trend, and aggressively defend their clients. The Times mentioned Susan Tipograph, whose efforts for the poor and oppressed have earned her a national reputation. David Krauss, another lawyer who handles primarily appointed cases, provides another example. The price these lawyers pay is heavy, however. They are not paid enough for their out-of-court investigative efforts to cover the overhead of their offices and support staff.

We can do the arithmetic that shows the New York system cannot provide effective assistance of counsel. Lawyers are paid twenty-five dollars per hour for out-of-court time, and forty dollars per hour for in-court work. Let us assume that a lawyer is as diligent as Susan Tipograph typically is, and that the case is difficult enough to require four hundred hours of out-of-court effort. This is not an unreasonable figure, when one considers that the lawyer should interview all the potential defense and prosecution witnesses, examine forensic reports, prepare and file legal motions, and visit the client. If the client is in jail, a single visit might require five or more hours to go to the jail and endure the nearly interminable wait to gain admittance to the lawyer visiting rooms.

Four hundred hours represents ten weeks of work. The lawyer would be paid ten thousand dollars-for which payment he or she will have to fill out forms and wait for approval and processing. That lawyer can expect to pay office rent of $\$ 250$ per week, or $\$ 2,500$ for ten weeks. If the lawyer has a half-time secretary/paralegal who earns only fifteen dollars per hour, that would amount to three thousand dollars. In addition to office rent, the lawyer must pay telephone, the cost of maintaining a minimal law library, office supplies and other expenses of running a business. Assume a modest fifty dollars per week for these expenses, for another five hundred dollars. Thus, ten thousand dollars nets out to four thousand dollars, which is four hundred dollars per week or ten dollars per hour. A poverty-level wage in New York City for a wage-earner with a family is eleven dollars per hour in 2001.

In addition, our hypothetical lawyer may be a recent law school graduate, who will bear an average of $\$ 100,000$ in debt for tuition and other educational expenses. Debt service will therefore consume at least $\$ 750$ per month under the most favorable conditions. Little wonder we read stories of dedicated lawyers who do a good job and live in coldwater flats to be able to do it.

On the other hand, the lawyer who goes to court every day and pretends to represents a half-dozen or more clients by making a series of quick plea bargains will earn forty dollars per hour for that work. Such a lawyer does not do any investigation or file any legal motions, and thus may have no need of secretarial help or a library of basic books.

As I ponder this information, I am reminded of my first appearance in the New York criminal courts. In a desperate attempt to preserve the image of justice, someone had put a big plastic bag over the American flag on the judge's dais. The bag was yellowed and grimy. Behind the judge, an incomplete set of tarnished metal letters proclaimed "IN GOD WE RUST"

The Supreme Court's attitude towards the role of counsel is illustrated in its recent decision, Texas v. Cobb. The Court held five to four that when an indigent gets counsel appointed to represent him for one crime, that representation bargain does not extend to other related offenses. Therefore, the state can treat the accused as 
being without counsel for any offense beyond that with which he is formally charged. Suppose, for example, that an indigent is found with an unlicensed weapon, and arrested on that charge. Counsel is appointed, and the accused is held in jail. The police suspect that this defendant might have committed another crime, such as using the weapon in a robbery. Even though the accused has counsel, and even though the lawyer has told the police that counsel should be present during questioning, and even though the police have agreed to that condition, the Supreme Court's decision means that the accused may be questioned without counsel being present. The Court's reasoning is that the contract of representation, as defined by and in the interest of the state, does not extend to protecting the accused's liberty generally, but only to defending the specific charge.

In addition, there are dozens of communities where defendants may be held without bail for weeks at a time, due to crowded court dockets. Because a poor person cannot post cash bond, he or she stays in jail. The racial disparity in arrest patterns is then compounded by the disparity between rich and poor. In these communities, it is often the practice not to appoint counsel until the defendant appears in court after the long delay. By this device, the accused is kept in jail for want of a lawyer to move for low bail or release on personal recognizance. The social consequences of this system are that the jailed accused, though presumed innocent, loses whatever employment he or she may have had, and risks a breakdown in family and community ties.

True, the constitution formally guarantees effective assistance of counsel. This ought to be, and could be if properly interpreted, a mechanism for ensuring that the contract between counsel and accused reflects the client's desires and interests. Not so.

In the world of commerce, when a wealthy person hires a lawyer, the lawyer is required to communicate with the client and to provide zealous and diligent representation. If the legal issues involved are complex or specialized, the lawyer must warn the client if he or she lacks the training and experience that may be required. The contract in this setting is dictated by the client's expressed goals, and the rules of legal ethics operate predominantly to require that the lawyer diligently and skillfully fulfill the bargain. The legal ethics do, however, require that the lawyer not assist the client in wrongdoing. In the main, however, the state through its courts and agencies supports the fulfillment of the wealthy client's desires and goals.

In sharp contrast, the relationship between the indigent accused and appointed counsel is governed by loose and discretionary standards. In reviewing a case to determine whether counsel was ineffective, the courts give wide latitude to so-called tactical decisions, including decisions not to investigate possible defenses, to refrain from crossexamining witnesses, and to make only token arguments to the jury. As the Supreme Court has said, "judicial scrutiny of counsel's performance must be highly deferential." "Deferential" to what? To the lawyer's decision to do less than might be done or than the client would wish.

The "judicial scrutiny," such as it is, is also problematic. If the appointed lawyer who served at trial is also appointed on appeal, as is the norm, she is unlikely to argue that her own performance was deficient. Once the appeals are over, if the defendant figures out while sitting in jail that he did not receive counsel's effective assistance, he has no right at that point to a lawyer to help him gather the facts and make those arguments. Once the direct appeals are over, the Supreme Court has held, the constitutional right to counsel evaporates entirely. So we have a jail population that has no effective way to challenge the unfairness of the trials or plea bargains that put them there.

Under current federal law, when a state prisoner seeks federal review of his conviction, and claims ineffective assistance of counsel, the federal court will deny relief if the state court's interpretation of constitutional law is not "unreasonable." For example, in a recent capital case, the federal court found that defense counsel was constitutionally deficient in failing to investigate evidence of the accused's horrid childhood and "torturous" prison experience. Yet, the federal court said, the Mississippi Supreme Court was not unreasonable in finding that counsel was adequate. To understand the horror of that decision, one should know that the Mississippi Supreme Court is elected. For a brief time in the 1970s, a justice of that court who had been appointed by the governor to fill a vacancy voted to reverse a couple of death penalty cases. He was swept from office the next election. 
This brings us to the contract that is related to that between the appointed lawyer and the client, and that is the plea bargain. A defendant is charged. The appointed lawyer points out that he could remain in jail and wait for trial, probably be convicted, and then spend significant jail time. On the other hand, a guilty plea would probably result in a lesser sentence, and for minor crimes release for "time already served." The lawyer, because of the nature of his "contract" with the client, is of course in a position to make the dark side of this dream come true, for his indifference and inattention would make conviction quite likely if the case were to be tried.

Thus begins a typical scenario in the 90 percent of all criminal cases that end in a plea bargain. The "contract" between the accused and the state follows a ritual form. The accused is asked if he understands the charges. At the lawyer's prodding he says yes. He is asked if he wishes to waive a trial, and all the rights to summon and crossexamine witnesses that would be involved in a trial. The accused, often sensing that he has no realistic choice, says yes. The judge then seals the bargain and imposes sentence.

What's wrong with this picture? Two main things: the purported consent is unreal, and the accused is not truly informed of the rights he is forfeiting. Recently, prosecutors have added a third dimension to the unfairness by seeking waivers of the right to appeal.

First, the issue of consent. A free bargain requires a freedom to choose. The prisoner being tortured may agree to make a statement, because he has no realistic choice. The worker may accept substandard working conditions because there is no other way to earn a wage. In the plea bargain setting, the lamentable quality of legal representation means that most indigent defendants cannot see any realistic way out of the plea bargain trap. To be sure, many defendants who plead are in fact guilty and are saving the state the trouble of trying them. But every year a distressing number of cases come to light where defendants are railroaded into plea bargains. And even when a "guilty" defendant pleads, the lawyer's bad performance can result in a harsher sentence than would be received if the lawyer had aggressively and imaginatively presented evidence and argument in support of a lighter sentence. In some Western European countries, such as France, the system requires counsel to work hard on the issue of potential punishment, with a corresponding reduction in prison sentences and prison population.

Second, the issue of informed consent. The Supreme Court has held that the defendant entering a guilty plea need only be told of the trial rights that he is forfeiting - that is, of his right to summon witnesses and so on. In addition, he must be told of the maximum sentence. It is doubtful that he must be told that his conviction might result in life imprisonment as the result of "three strikes" laws that mandate such a sentence on conviction of three felonies. The Supreme Court has held that the defendant need not be told that he would have a right to challenge unlawful police activity, or other important procedural rights that supposedly restrain the state. Thus the defendant may never hear of how asserting those procedural rights could result in dismissal of the charges or a better bargain.

The newer wrinkle in all of this is the by-now routine prosecution insistence that the defendant, as part of the bargain, affirmatively promise never to challenge the plea bargain as unfair. In ordinary commerce, this would be like buying a car after a strong sales pitch, and under pressure to purchase, and being forced to agree that you could not bring the car back to the dealer even if it was lethally unsafe. Some appellate courts are questioning the validity of such agreements, but they often, and perhaps mostly, are upheld.

So we are shoveling people into the prisons at this enormous rate. The root causes are no doubt overcriminalization and racially-biased police and prosecution decisions. But the twin and phony contracts between lawyer and client and between client and the state gravely weaken the ostensible constitutional provisions that are designed to provide review and remedy for those sorts of abuses.

Two questions remain. What moves this system in this direction? And is effective counsel simply a dream? The system moves in this way because lawyers neither own the means of production nor labor in ways that supply them with class consciousness. People of color are under-represented in the ranks of lawyers, and only in the past twenty years have any significant number of Chicano lawyers entered the profession, when entry is measured in percentage of the Chicano population. Once in the legal profession, people of color tend to be relegated to its lowest rungs and 
face race-based obstacles to advancement. One ticket to advancement is to abandon the cause of racial justice. Law school programs designed to redress historic inequality are increasingly under attack.

Lawyers consume surplus value, and those with surplus value to distribute are mainly on the side of this repressive system. Labor organizations also hire lawyers, but the valiant work of these lawyers deals mostly with worker rights and not criminal justice.

It is a wonder that there is much challenge at all to the system this issue describes, yet there are challenges. As in times past, lawyers overcome their class-based bias and enter the struggle for change. In Law and the Rise of Capitalism, reissued in a new edition in 2000 , I discussed the role and importance of these lawyers. They do not stand at the center of events, but they assist those who are at the center or who are brought into conflict with the state. Lawyers help to turn claims for justice into coherent demands and principles. They may show the open spaces within an old system, where change can be successful. When the open spaces close up, they can help define the conditions on which a new order will be created.

Some question my picture of lawyers' potential role. Yet in struggle after struggle, fighters for justice have drawn on legal ideology. Nelson Mandela and Oliver Tambo were lawyers, and their continued calls for justice were phrased in terms of the legal ideology that would emerge in a transformed South Africa.

Honorable public defenders and appointed counsel, of whom there are many, fight the system one battle at a time. We salute them, while remembering Yevgeny Yevtushenko's words:

How sharply our children will be ashamed

Taking at last their vengeance for these horrors

That in so strange a time

Common integrity could look like courage

In some law schools, such as Washington College of Law, American University, where I teach, clinical legal education helps to prepare lawyers to meet the challenges that this system poses. Nationally, however, only about 3 percent of law graduates go into public interest law, compared with some 15 percent twenty-five years ago. At WCL, we manage to place about three times the national average in such jobs. But restrictions on funding for defender services, state and federal, have seriously eroded the job opportunities in that sector. Meanwhile, the law graduate who goes into public interest work will earn less than 20 percent of what a graduate who enters private practice can expect. Twenty-five years ago, the disparity was much less-about half. Concerned law students should join up with such progressive organizations as the National Lawyers Guild.

However, human rights organizations have creatively attacked the system's unfairness by class action lawsuits that further the demands of many defendants and target entire jail or prosecutorial systems. For example, the Southern Center for Human Rights under the leadership of Steven Bright, has effectively litigated for better medical care and better access to counsel to make bail motions. Similar lawsuits have been brought by the Prisoners Rights Project and the Center for Constitutional Rights.

The large-scale class action is significant for the same reason that civil rights litigation of the 1940s, 1950s, and 1960 s played a constructive role. Given the real world of conservative judges, this kind of litigation faces significant obstacles to courtroom success. Like much class suit litigation, however, the lawsuit can serve as a means to focus public attention on issues. It can and should be part of a broader organizing effort. In this arena as in others, the community's demands and needs, and not the lawyer's view of the world, have pride of place.

\section{Sources}

Angela Jordan Davis, The American Prosecutor: Independence, Power and the Threat of Tyranny, 86 lowa L. Rev. 393 (2001) contains many useful citations. 
The Supreme Court case on lawyer speech is Gentile v. State Bar of Nevada, 501 U.S. 1030 (1991). It must be noted, however, that the Court did reverse the disciplinary action against Mr. Gentile on first amendment grounds, while a separate majority of the Court set a standard for future cases.

The case limiting the appointed lawyer's representation to the specific case is Texas v. Cobb, No. 99-1702 (April 2, 2001).

The study of death penalty counsel is part of a superb Symposium, Carter Center Symposium on the Death Penalty, 14 Ga. St. U. L. Rev. 329 (1998).

Ineffective assistance of counsel cases include Strickland v. Washington, 466 U.S. 668 (1984).

On waiver of rights, see Michael E. Tigar, Foreword: Waiver of Constitutional Rights: Disquiet in the Citadel , 84 Harv. L. Rev. 1 (1970).

The New York Times articles ran April 8-10, 2001, and are on the Times website at http://www.nytimes.com/2001/04/08/nyregion/08LAWY.html;

http://www.nytimes.com/2001/04/09/nyregion/09LEGA.html; http://www.nytimes.com/2001/04/10/nyregion/10LAWY.html.

The Mississippi case is Neal v. Puckett, 2001 WL 43274 (5th Cir. 2001). 